\title{
EFEK ZAT AKTIF EKSTRAK DAUN JAMBU BIJI MERAH (PSIDIUM GUAJAVA.L) TERHADAP SPERMATOGENESIS PADA TIKUS PUTIH JANTAN (RATTUS NORVEGICUS)
}

\author{
(Effects of Red Guajava Leaf Extract (Psidium Guajava. L) Active Substance on FSH Level and \\ Spermatogenesis in Male White Rats (Rattus Norvegicus))
}

\author{
Ervi Husni, Sukesi \\ Poltekkes Kemenkes Surabaya, J1. Pucang Jajar Tengah no. 56 Surabaya, 60282 \\ Email: ervie.dh@gmail.com
}

\begin{abstract}
ABSTRAK
Pendahuluan: Jumlah penduduk Indonesia sensus tahun 2010 sebanyak 237,6 juta jiwa dengan laju pertumbuhan penduduk 1,49\% per tahun. Target RPJPMN 2010-2014 sebesar1,14 \%, laju pertumbuhan penduduk saat ini $0,53 \%$ masih lebih tinggi. Pengendalian penduduk diperlukan antara lain dengan pemakaian kontrasepsi pada wanita maupun pria. Keterlibatan pria dalam KB masih rendah hanya 6,26\%. Tujuan penelitian untuk membuktikan zat aktif daun jambu biji merah dapat menurunkan kadar FSH dan spermatogenesis pada tikus putih jantan (Rattus norvegikus). Metode: Penelitian ini merupakan penelitian eksperimen dengan rancangan Post test only control group design. Besar sampel menggunakan rumus Federer dengan jumlah sampel 30 ekor tikus putih, terbagi tiga kelompok yaitu Kelompok 1 (K1) kelompok kontrol diberikan larutan CMC 0,5 \% $1 \mathrm{ml} /$ hari, Kelompok Perlakuan 1 (P1) diberikan ekstrak daun jambu biji merah dosis $40 \mathrm{mg} / \mathrm{ml} / \mathrm{hari}$ dan kelompok Perlakuan 2 (P2) diberikan ekstrak daun jambu biji merah dosis $80 \mathrm{mg} / \mathrm{ml} / \mathrm{hari}$ dan diberikan selama 30 hari. Variabel penelitian jumlah sel spermatogenik ( Spermatogonium, Spermatosit primer dan Spermatid). Data dianalisis menggunakan uji ANOVA. Hasil: Hasil analisis data dengan uji ANOVA jumlah sel spermatogonium nilai $p$ 0,801 (p < 0,05): tidak ada perbedaan signifikan diantara ketiga kelompok, uji LSD tidak dilakukan. Hasil uji ANOVA untuk jumlah sel spermatosit primer didapatkan nilai p 0,102 ( $\mathrm{p}<0,05)$, berarti tidak ada perbedaan signifikan diantara ketiga kelompok, uji LSD tidak dilakukan. Hasil uji ANOVA untuk jumlah sel spermatid nilai $p 0,001 \quad(p<0,05)$ berarti terdapat perbedaan signifikan diantara ketiga kelompok. Hasil uji LSD kontrol dengan P1 (p 0,036): berbeda, Kontrol dengan P2 (p <0,000): berbeda, P1 dengan P2 ( $<0,033)$ : berbeda. Diskusi: Kesimpulan penelitian ini adalah pemberian ekstrak daun jambu biji merah tidak menurunkan jumlah sel spermatogonium dan sel spermatosit primer tetapi menurunkan jumlah spermatid pada tikus putih jantan.
\end{abstract}

Kata kunci: Ekstrak daun jambu biji merah (Psidium guajava.L, sel spermatogenik (spermatogoniun, spermatosit primer dan spermatid).

\begin{abstract}
Introduction: The census in 2010 showed that the population of Indonesia was as many as 237.6 million with a population growth rate of $1.49 \%$ per year. RPJPMN target in $2010-2014$ was $1.14 \%$, so the current population growth rate, which is $0.53 \%$, is still high. It is necessary to control population growth. One method to control population is the use of contraception by using contraceptive both in males and females. Male involvement in family planning remains low, only $6.26 \%$. The purpose of this study was to proved that the active substance of red guava leaves can reduce spermatogenesis in male rats (Rattus norvegicus). Methods: This was an experimental study using post-test only control group design. Sample size from Federer's formula obtained 30 white rats. Samples were divided into three groups: Group 1 (K1), the control group, was given with $0.5 \%$ CMC Na solution of $1 \mathrm{ml} /$ day. Treatment group 1 (P1) was given red guajava leaf extract in a dose of $40 \mathrm{mg} / \mathrm{ml} /$ day, and the treatment group 2 (P2) was given with red guajava leaf extract in a dose of $80 \mathrm{mg} / \mathrm{ml} /$ day for 30 days. The variables in this study were spermatogenic cell count. Data were analyzed using ANOVA test. Result: Results of ANOVA data analysis, number of spermatogonial cells had $p$ value 0.801 ( $p<0.05)$, it means there was no significant difference among the three groups, LSD test was not conducted. ANOVA test results for a number of primary spermatocytes cells showed $p$ value 0.102 ( $p<0.05)$, there were no significant differences among the three groups, LSD test was not conducted. ANOVA test results for a number of spermatid cells $p$ value of $0.001(p<0.05)$ means that there were significant differences among the three groups. LSD test results with P1 control ( $p$ 0.036): different, with P2 controls $(p<0.000)$ : different, P1 to P2 ( $p<0.033$ ): different. Discussion: The conclusion of this study was that the administration of guajava leaf extract does not reduce spermatogonium and spermatosit primer but reduce spermatid count in male rats.
\end{abstract}

Key words: red guava (Psidium guajava. L) leaf extract, spermatogenic cells

\section{PENDAHULUAN}

Pengendalian jumlah penduduk yang telah dilaksanakan oleh pemerintah antara lain melalui pengendalian angka kelahiran berupa program Keluarga Berencana (Moeloek 1994). Usaha yang telah dilaksanakan dalam program $\mathrm{KB}$ adalah penyediaan sarana kontrasepsi. Kontrasepsi prinsipnya mencegah terjadinya peleburan antara sel sperma pria dengan sel telur wanita. Saat ini lebih banyak ditujukan pada kaum wanita, pada pria masih terbatas, sehingga perkembangan kontrasepsi pria jauh tertinggal (Prajogo. B 2003). Sensus penduduk tahun 2000, penduduk Indonesia 205,8 juta jiwa. Laju pertumbuhan 
penduduk periode 2000-2010 sekitar 1,45\% per tahun. Penduduk indonesia hasil sensus tahun 2010 menjadi 237,6 juta jiwa dengan laju pertumbuhan penduduk $1,49 \%$ per tahun. Dibandingkan Rencana Pembangunan Jangka Menengah Nasional (RPJMN) 2010-2014 sebesar $1,14 \%$, maka laju pertumbuhan penduduk saat ini $0,53 \%$ masih lebih tinggi (BKKBN, 2014). Jumlah penduduk yang tinggi tidak diikuti peningkatan kualitas hidup, terlihat dari belum terpenuhinya hak warga negara seperti kecukupan pangan, kualitas pendidikan yang bermutu, lingkungan, dan gaya hidup sehat, serta keamanan fisik dan sosial. Diperlukan pengendalian jumlah penduduk. (Shihab, 2005). Laporan hasil pelayanan kontrasepsi Oktober 2013 jumlah peserta baru menurut jenis kontrasepsi yaitu : peserta IUD 7,78 \%, MOW 1,54 \%, Implan 9,29\%, Suntik 48,78\%, Pil 26,34\% dan MOP 0,26\%, Kondom 6,00 \% . Keikutsertaan pria dalam program $\mathrm{KB}$ masih sangat rendah yaitu hanya sebesar 6,26 \% (BKKBN, 2014).

Proses spermatogenesis dikendalikan oleh poros hipotalamus hipofisis dan testis. Gonadotropin realeasing hormon $(\mathrm{GnRH})$ dilepaskan oleh hipotalamus sampai pada sasaran hipofise anterior. GnRH merangsang kelenjar hipofisa mengeluarkan homon gonadotropin FSH dan LH yang akan mempengaruhi testis untuk berfungsi. FSH menstimulasi pertumbuhan sel-sel germinatif dari tubulus seminiferus dan mendorong terjadinya proses spematogenesis secara sempurna. LH menstimulasi aktivitas dan pertumbuhan sel Leydig dalam jaringan interstitial untuk menghasilkan hormon testosteron. Spermatogenesis dikendalikan oleh interaksi hormon FSH, LH dan testosteron, gangguan interaksi ini dapat menyebabkan proses spematogenesis terganggu (Speroff L \& Fritz 2005; Ganong. WF 2003). Hilangnya hormon gonadotropin akan mempunyai dampak pada berhentinya proses spermatogenesis, atropi testis dan tenunan testis menjadi lunak (Harjopranjoto. S 1995).

Penggunaan kontrasepsi asal tanaman perlu diperhatikan sifat merusak atau pengaruhnya terhadap sistim reproduksi baik pada pria maupun wanita. Sebaiknya digunakan tanaman yang sifatnya sementara (reversibel), bila tidak digunakan lagi sistem reproduksi kembali normal sehingga tidak terjadi kemandulan dan diharapkan dapat menurunkan fertilitas $100 \%$ (Winarno, dalam Susetyarini. Rr. E 2009). Bahan obat-obatan dari tanaman mempunyai keuntungan antara lain toksisitasnya rendah, mudah diperoleh, murah harganya dan kurang menimbulkan efek samping (Arsyad, 1986). Tanaman yang diharapkan dapat menjadi antifertilitas adalah daun jambu biji merah (Psidium guajava L). Daun jambu biji merah mengandung zat aktif seperti alkaloid, flavonoid, tanin, minyak atsiri, avicullarin, oleanolic acid dan beta-sitosterol yang diduga bersifat antifertilitas. Alkaloid dapat mempengaruhi sekresi hormon reproduksi yang diperlukan untuk berlangsungnya proses spermatogenesis, minyak atsiri bekerja tidak pada proses spermatogenesis tetapi pada transportasi sperma, tanin dapat menggumpalkan sperma sehingga menurunkan motilitas dan daya hidup sperma (Wien dan Dian, 2007). Alkaloid yang bekerja menekan sekresi FSH dan LH sehingga akan mengganggu proses spermatogenesis dan akibatnya juga akan berpengaruh terhadap kualitas dan kuantitas spermatozoa (Toelihere dalam Hartini 2011). Menurut Indriani (2006) ekstrak etanol daun jambu biji mengandung senyawa tanin dan steroid yang tinggi serta sedikit senyawa hidrokuinon, flavonoid dan saponin. Variabel yang di ukur adalah kadar FSH dan jumlah sel spermatogenik (spermatogonium, spermatosit primer dan spermatid)

\section{BAHAN DAN METODE}

Penelitian ini merupakan penelitian eksperimen, dengan rancangan penelitian Post test only control group design. Subjek penelitian terdiri dari tiga kelompok yang dipilih secara acak dan telah diadaptasikan. Masing-masing kelompok sebanyak 10 ekor dan dibagi dalam tiga kelompok. Satu kelompok sebagai kontrol hanya mendapatkan $\mathrm{CMC} \mathrm{Na}$ $0,5 \%$ saja per oral. Sedangkan dua kelompok lainnya mendapat perlakuan 1 dan perlakuan 2 diberikan suspensi ekstrak daun jambu biji merah dengan dosis $40 \mathrm{mg} / \mathrm{ml} /$ hari dan $80 \mathrm{mg} / \mathrm{ml} /$ hari selama 30 hari. Penelitian ini menggunakan tikus putih jantan (Rattus norvegicus) strain wistar di fakultas kedokteran hewan Unair, karena secara etik tidak memberikan perlakuan secara langsung kepada manusia. Uji kelaikan etik (Ethical clearance) dilaksanakan sebelum penelitian eksperimental laboratoris yang sesungguhnya Fakultas Kedokteran Hewan Universitas Airlangga.

Bahan yang digunakan untuk penelitian ini adalah tumbuhan daun jambu biji merah diperoleh dari Balai Penelitian Tanaman Obat dan Herbal Departemen Pertanian jalan Tentara 
Pelajar no 3 Bogor Jawa Barat. Kemudian daun jambu biji merah dibuat simplisia (serbuk) lalu di ekstraksi. Dari $2 \mathrm{~kg}$ daun jambu biji merah didapatkan $1300 \mathrm{~g}$ serbuk kering daun jambu biji. Minuman yang diberikan adalah air PDAM ad libitum dan makanan yang diberikan adalah makanan tikus putih pada umumnya.

Alat untuk perlakuan yaitu botol kecil, sonde, gelas ukur, corong gelas kecil. Alat untuk pengambilan preparat histologi testis yaitu alat bedah, cawan petri. Alat untuk menghitung sel spermatogonium, spermatosit primer dan spermatid yaitu mikroskop cahaya, counter pipet, gelas objek cekung dan stop wacth . Alat untuk ekstraksi yaitu shaker, tabung Erlenmeyer, rotary evaporator, penghitungan menggunakan hemositometer

Tahap Persiapan meliputi:

1. Tikus putih jantan dewasa yang memenuhi kriteria baik umur maupun berat badan disiapkan sebanyak 30 ekor.

2. Melakukan adaptasi lingkungan selama 1 minggu untuk penyesuaian terhadap lingkungan dengan memberi makan dan minum tikus seperti biasa.

3. Pengelompokan tikus yaitu satu kelompok kontrol dan 2 dua kelompok perlakuan yang masing- masing kelompok sebanyak 10 ekor.

4. Tikus ditempatkan dalam kandang yang terbuat dari bahan plastik tertutup kawat sebanyak 10 buah dilengkapi tempat makan dan botol minuman. Kandang berukuran $40 \times 50 \mathrm{~cm}$, sekam sebagai alas kandang di bersihkan setiap dua hari. Lingkungan kandang tikus putih dengan suhu kandang dibiarkan dalam kisaran alamiah $\left(27-27,5^{\circ} \mathrm{C}\right)$. Cahaya ruangan 12 jam terang dan 12 jam gelap. Timbangan sartorius untuk menimbang berat badan tikus putih. Makan adalah makanan tikus biasa (pelet) dan air minun PDAM disuplai setiap hari.

5. Pembuatan suspensi $\mathrm{CMC} \mathrm{Na} 0,5 \%$. Ditimbang 0,5 gram serbuk CMC Na 0,5 $\%$, air panas sebanyak $40 \mathrm{ml}$ ditaburkan di mortal, dibiarkan terendam dan mengembang beberapa menit. Kemudian ditambahkan air mineral sampai volume $100 \mathrm{ml}$ dan dikocok kemudian dipindahkan ke gelas.

6. Membuat suspensi ekstrak daun jambu biji merah. Daun jambu biji diiris-iris lalu dikeringkan, setelah kering lalu ditumbuk halus menjadi serbuk. Tiap $2 \mathrm{~kg}$ daun jambu biji (basah) dapat menghasilkan $500 \mathrm{~g}$ serbuk. Serbuk daun jambu biji sebanyak 500 gram dimaserasi dalam pelarut etanol sebanyak 1 liter sehari semalam (diulang 3 kali). Filtrat diuapkan dalam rotary evaporator pada suhu $40^{\circ} \mathrm{C}$ sampai terbentuk ekstrak etanol. Evaporasi dihentikan jika sudah terbentuk uap lagi. Maserasi diulang hingga filtrat jernih seperti etanol. Ekstrak cair yang diperoleh lalu dipekatkan dengan rotavapor. Kemudian dilakukan skrining fitokimia yang bertujuan untuk mengetahui golongan senyawa yang terkandung dalam suatu bahan tanaman.. Suspensi ekstrak daun jambu biji merah dibuat untuk kebutuhan 1 minggu dan pembuatan dilebihkan untuk mengantisipasi bila ada suspensi yang tumpah saat pengambilan. Cara pembuatan suspensi dosis $40 \mathrm{mg} / \mathrm{ml} /$ hari yaitu : $40 \mathrm{mg} \times 7$ hari $\times 15=4200 \mathrm{mg}(4,2 \mathrm{~g})$, kemudian di

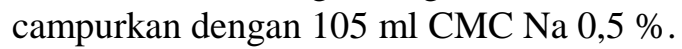
Cara penghitungan yang sama juga dilakukan untuk pembuatan suspensi dosis $80 \mathrm{mg} / \mathrm{ml} / \mathrm{hari}$.

Tahap Pelaksanaan:

1. Memberikan perlakuan dengan cara memberikan larutan CMC 0,5\% $1 \mathrm{ml} /$ hari pada kelompok kontrol dan memberikan ekstrak daun jambu biji merah dosis $40 \mathrm{mg} / \mathrm{ml} /$ hari pada kelompok perlakuan 1 serta $80 \quad \mathrm{mg} / \mathrm{ml} / \mathrm{hari}$ pada kelompok perlakuan 2 setiap hari pada jan 12.00 wib setiap hari selama 30 hari.

2. Setelah hari ke 30 tikus disiapkan untuk pengambilan sampel jumlah sel spermatogenik. Dilakukan setelah perlakuan terhadap hewan coba berakhir. Tikus dikorbankan dengan menggunakan eter, setelah mati kemudian Testisnya di ambil untuk pembuatan histologi testis. Epididimis yang diambil adalah bagian kauda.dan diletakkan di cawan petri yang berisi larutan saline/PBS $1 \mathrm{ml}$, kemudian dipotong-potong halus hingga terbentuk suspensi.

3. Untuk pemeriksaan sel spermatogeniknya organ testis dimasukkan kedalam larutan buoin, kemudian dibuat sediaan histologi dengan pewarnaan hematoksilin eoisin. Pengamatan dilakukan dilakukan dengan mikroskop cahaya dengan pembesaran 400 kali, sampel diambil sebanyak lima lapangan pandang dan diambil rata-rata jumlah sel permatogenik. 
Data yang diperoleh adalah nilai rerata dari jumlah sel spermatogenik meliputi spermatogonium, spermatosit primer dan spermatid tiap kelompok. Data hasil penelitian disajikan dalam bentuk tabel. Distribusi data normal atau tidak dilakukan uji KolmogorovSmimov $Z$ dan untuk mengetahui varian homogen atau tidak dilakukan uji homogenitas varian. Hasil uji homogenitas varian apabila varian homogen dilanjutkan dengan uji Anova satu arah pada taraf signifikansi $p<0,05$ dan untuk mengetahui bermakna atau tidaknya beda antar pasangan perlakuan dilakukan uji LSD (Least Significantly Difference) $(\mathrm{BNT}=$ Beda Nyata Terkecil) (Steel dan Torrie, 1991).

\section{HASIL PENELITIAN}

\section{Jumlah Sel Spermatogenik}

\section{Jumlah spermatogonium}

Jumlah spermatogonium adalah jumlah yang dihitung dengan menggunakan mikroskop Nikon Eclipse $\mathrm{Ci}$ dengan pembesaran 400 kali pada preparat histologi testis dari sayatan tubulus seminiferus dengan pewarnaan Hematoksilin Eosin yang dilakukan pada lima lapang pandang dan dinyatakan dalam bentuk jumlah sel (sel per lapang pandang).

Hasil perhitungan jumlah rerata spermatogonium pada tikus putih jantan tidak terdapat perbedaan yang bermakna antara kelompok kontrol dengan kelompok P 1 dan kelompok P2. Hasil Uji normalitas KolmogorovSmirnov pada kelompok kontrol menunjukkan nilai $\mathrm{p} \quad 0,710$, kelompok $\mathrm{P} 1$ nilai $\mathrm{p} 0,989$ dan pada kelompok P 2 nilai p 0,859 ( $\mathrm{p}>$ $0,05)$, berarti ketiga data berdistribusi normal. Dilanjutkan uji statistik dengan menggunakan uji Anova satu arah, didapatkan nilai p 0,801 (p <
0,05), berarti tidak ada perbedaan yang signifikan diantara ketiga kelompok. Nilai significant of level nya $>0,05$, maka disimpulkan tidak ada perbedaan yang bermakna pada ketiga kelompok, untuk itu uji LSD (least square difference) tidak bisa dilakukan. Jumlah spermatogonium tikus putih jantan pada ketiga perlakuan secara statistik dianggap tidak berbeda signifikan (Tabel 1).

\section{Jumlah spermatosit primer}

Jumlah spermatosit primer adalah jumlah yang dihitung dengan menggunakan mikroskop Nikon Eclipse Ci dengan pembesaran 400 kali pada preparat histologi testis dari sayatan tubulus seminiferus dengan pewarnaan Hematoksilin Eosin yang dilakukan pada lima lapang pandang dan dinyatakan dalam bentuk jumlah sel (sel per lapang pandang).

Hasil perhitungan jumlah rerata spermatosit primer pada tikus putih jantan didapatkan penurunan antara kontrol dengan kelompok $\mathrm{P}$ 1 dan kelompok P2. Hasil Uji normalitas Kolmogorov-Smirnov pada kelompok kontrol menunjukkan nilai p 0,124, kelompok perlakuan 1 nilai p 0,799 dan pada kelompok Perlakuan 2 nilai $\mathrm{p} 0,937(\mathrm{p}>0,05)$ yang berarti bahwa ketiga data tersebut berdistribusi normal. Kemudian dilanjutkan dengan uji statistik dengan menggunakan uji Anova satu arah, didapatkan nilai p 0,102 $(\mathrm{p}<0,05)$. Tidak ada perbedaan yang signifikan diantara ketiga kelompok. Nilai significant of level nya $>0,05$ maka disimpulkan tidak ada perbedaan pada ketiga kelompok perlakuan, uji LSD ( least square difference ) tidak bisa dilakukan. Jumlah spermatosit primer tikus putih jantan pada ketiga perlakuan secara statistik terbukti tidak berbeda signifikan (Tabel 2).

Tabel 1 Rata-rata $(\bar{x})$ dan simpangan baku (SD) jumlah spermatogonium pada tikus putih jantan

\begin{tabular}{ccc}
\hline Kelompok & Replikasi & $\bar{\alpha} \pm \mathrm{SD}$ \\
\hline K (kontrol) & 10 & $57,780 \pm 5,46^{\mathrm{a}}$ \\
P1 (40 mg/ml/hari) & 10 & $58,400 \pm 11,64^{\mathrm{a}}$ \\
P2 (80 mg/ml/hari) & 10 & $55,580 \pm 6,69^{\mathrm{a}}$
\end{tabular}

p: 0.801

Keterangan : superskrip huruf yang sama menunjukkan tidak berbeda nyata

Tabel 2 Rata-rata $(\bar{x})$ dan simpangan baku (SD) jumlah spermatosit primer pada tikus putih jantan

\begin{tabular}{ccc}
\hline Kelompok & Replikasi & $\bar{\alpha} \pm$ SD \\
K (kontrol) & 10 & $81,570 \pm 8,86^{a^{a}}$ \\
P1 $(40 \mathrm{mg} / \mathrm{ml} /$ hari $)$ & 10 & $70,710 \pm 10,63^{\mathrm{a}}$ \\
P2 $(80 \mathrm{mg} / \mathrm{ml} /$ hari $)$ & 10 & $56,850 \pm 10,60^{\mathrm{a}}$ \\
\hline$\rho: 0.102$ & & \\
\hline
\end{tabular}

Keterangan : superskrip huruf yang sama menunjukkan tidak berbeda nyata 
Tabel 3 Rata-rata $(\bar{x})$ dan simpangan baku (SD) jumlah spermatid pada tikus putih jantan

\begin{tabular}{lcl}
\hline \multicolumn{1}{c}{ Kelompok } & Replikasi & $\bar{\alpha} \pm$ SD \\
\hline K (kontrol) & & $149,540 \pm 31,46^{\mathrm{a}}$ \\
P1 $(40 \mathrm{mg} / \mathrm{ml} / \mathrm{hari})$ & 10 & $120,830 \pm 17,39^{\mathrm{b}}$ \\
$\mathrm{P} 2(80 \mathrm{mg} / \mathrm{ml} / \mathrm{hari})$ & 10 & $91,600 \pm 35,12^{\mathrm{c}}$ \\
\hline$\rho: 0.001$ & 10 & \\
\hline
\end{tabular}

Keterangan : superskrip huruf yang berbeda menunjukkan berbeda nyata.

\section{Jumlah spermatid}

Jumlah spermatid adalah sel yang dihitung dengan menggunakan mikroskop Nikon Eclipse Ci dengan pembesaran 400 kali pada preparat histologi testis dari sayatan tubulus seminiferus dengan pewarnaan Hematoksilin Eosin yang dilakukan pada lima lapang pandang dan dinyatakan dalam bentuk jumlah sel (sel per lapang pandang).

Hasil perhitungan jumlah rerata spermatid pada tikus putih jantan didapatkan penurunan antara kontrol dengan kelompok perlakuan 1 dan perlakuan 2. Hasil Uji normalitas Kolmogorov-Smirnov pada kelompok kontrol menunjukkan nilai p 0,888 kelompok perlakuan 1nilai p 0,890 dan pada kelompok Perlakuan 2 nilai p 0,620 ( $\mathrm{p}>0,05$ ) yang berarti bahwa ketiga data tersebut berdistribusi normal. Kemudian dilanjutkan dengan uji statistik dengan menggunakan uji Anova satu arah, didapatkan nilai p 0,001 ( $\mathrm{p}$ $<0,05)$. Ada perbedaan yang signifikan diantara ketiga kelompok. Untuk mengetahui kelompok mana yang berbeda maka dilanjutkan dengan uji Least Significant Difference (LSD).
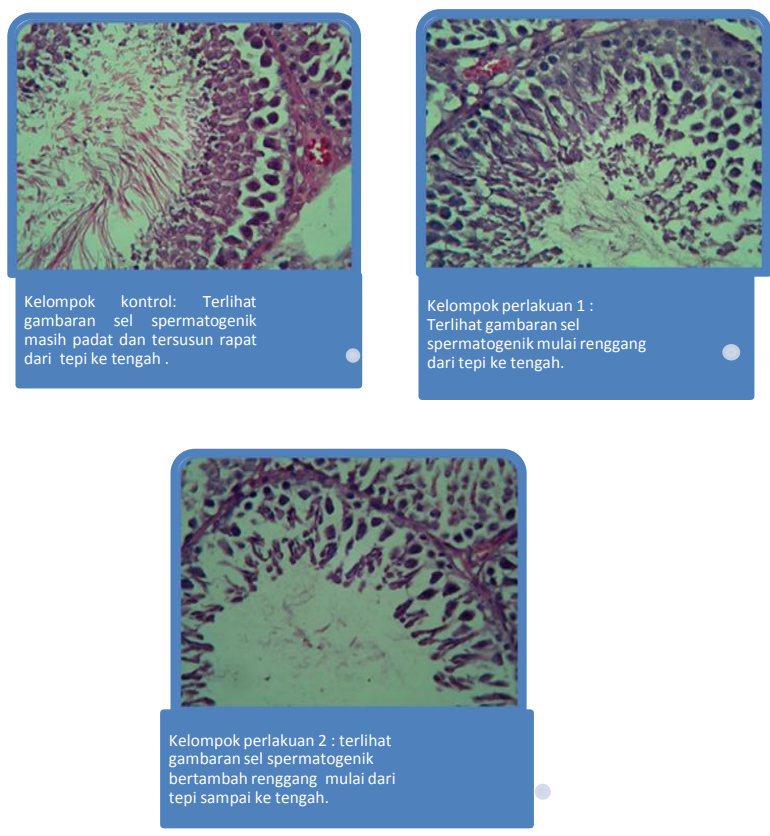

Gambar 1 Histologi testis sampel

\section{PEMBAHASAN}

\section{Jumlah Sel Spermatogenik}

Hasil perhitungan jumlah rerata spermatogonium pada tikus putih jantan tidak terdapat perbedaan yang bermakna antara kelompok kontrol dengan kelompok perlakuan 1 dan perlakuan 2. Dari hasil uji Anova satu arah, didapatkan nilai $\mathrm{p}=0,140(\mathrm{p}<0,05)$. Berarti tidak ada perbedaan yang signifikan diantara ketiga kelompok.

Tabel 2 menunjukkan hasil perhitungan jumlah rerata spermatosit primer pada tikus putih jantan didapatkan penurunan antara kontrol dengan kelompok perlakuan 1 dan perlakuan 2. Dari hasil uji Anova satu arah, didapatkan nilai $\mathrm{p}$ 0,102 ( $\mathrm{p}<0,05)$. Berarti tidak ada perbedaan yang signifikan diantara ketiga kelompok.

Jumlah spermatogonium dan spermatosit primer tikus puth jantan pada ketiga perlakuan secara statistik dianggap tidak berbeda signifikan. Artinya ekstrak daun jambu biji merah dengan dosis $40 \mathrm{mg} / \mathrm{ml} / \mathrm{hari}$ dan $80 \mathrm{mg} / \mathrm{ml} /$ hari selama 30 hari belum memberikan efek terhadap penurunan jumlah spermatogonium dan spermatosit primer pada tikus putih jantan.

Pada tabel 3 menunjukkan hasil perhitungan jumlah rerata spermatid pada tikus putih jantan didapatkan penurunan pada kelompok perlakuan 1 dan perlakuan 2 dibanding kelompok kontrol. Hasil uji Anova satu arah, didapatkan nilai $\mathrm{p} \quad 0,001(\mathrm{p}<0,05)$. Berarti ada perbedaan yang signifikan diantara ketiga kelompok. Hasil uji LSD menunjukkan bahwa ada perbedaan yang bermakna antara kelompok kontrol dengan kelompok P 1 dengan nilai p 0,036 sedangkan kelompok kontrol dengan P 2 juga terdapat perbedaan yang bermakna dengan nilai $\mathrm{p} 0,000$. Untuk kelompok $\mathrm{P} 1$ dengan $\mathrm{P} 2$ juga terdapat perbedaan yang bermakna dengan nilai $\mathrm{p} 0,033$.

Hasil gambaran histologi testis pada kelompok kontrol (gambar 1) terlihat potongan tubulus seminiferus testis terlihat sel-sel spermatogenik yang tersusun secara lengkap dan berurutan ke arah lumen menurut tingkat perkembanganya, sedangkan 
pada kelompok perlakuan 1 dan perlakuan 2 terlihat susunan sel longgar tidak beraturan dan kerapatannya berkurang.

Sel spermatogenik tersusun secara lengkap dengan sel yang berasosiasi secara berurutan kearah lumen menurut tingkat perkembangannya yaitu spermatogonium selapis, spermatosit primer, spermatid beberapa lapis dan lumen berisi spermatozoa (Astuti NY dan Soeradi O 2002). Sel spermatozoa yang dihasilkan di tubulus seminiferus testis oleh sel-sel yang berasal dari germinal epitelium disebut spermatogonium yang bersifat spermatogenik.

Pembentukan sel spermatogonium dalam tubulus seminiferus berturut-turut dari tepi ke arah lumen adalah yang dimulai dari spermatogonium yang sudah terbentuk semenjak sebelum pubertas. Spermatogonium akan berubah menjadi spermatosit primer, spermatosit sekunder dan kemudian berkembang menjadi spermatid. Spermatid akan melewati proses maturasi untuk berkembang menjadi sel spermatozoa (Poernomo, 2011).

Menurut Fritz (1978) perkembangan dan jumlah sel spermatogonia serta sel sertoli lebih dipengaruhi oleh regulasi hormonal. FSH berperan sejak terjadinya proliferasi spermatogonia sehingga terbentuknya spermatosit primer dan terhadap perkembangan tahap akhir spermatid menjadi spermatozoa. FSH dan androgen (testosteron) mempertahankan fungsi gametogenik testis. FSH bekerja pada sel sertoli untuk memperlanjar stadium akhir pematangan (Ganong. WF 2003). Sel endotelial dari epididimis membutuhkan andogen dalam level tinggi untuk berfungsi secara normal. Meski banyak testosteron yang disekresikan ke dalan tabung tubulus seminiferus diubah kedalam bentuk DHT oleh enzim 5a-steroidereduktase, beberapa testosteron diubah ke estrogen oleh enzim aromatase. Jumlah tertosteron yang cukup banyak dibutuhkan untuk pendewasaan spermatid (Hafez. 2000).

Sel spermatogenik sangat peka terhadap senyawa toksik pada saat mitosis I, Meiosis I dan spermatogenesis (Arsyad dalam Astuti NY dan Soeradi O 2002). Pada penelitian ini di duga bertambahnya jumlah lapisan spermatosit primer pada perlakuan mungkin disebabkan oleh adanya gangguan pada pembelahan meiosis. Zat aktif daun jambu biji merah diduga menghambat perubahan spermatosit primer menjadi spermatid sehingga terlihat lebih banyak sementara jumlah lapisan sel spermatid berkurang. Penurunnya jumlah spermatid dalam penelitian ini di duga dipengaruhi oleh kadar hormon testosteron yang masih rendah padahal hormon testosteron sangat diperlukan untuk pendewasaan spermatid. Berkurangnya jumlah lapisan sel spermatozoa pada lumen terjadi karena jumlah spermatid berkurang dan ditambah dengan adanya gangguan spermatogenesis sehingga spermatid terhambat untuk berdiferensiasi menjadi spermatozoa. Kerusakan di duga karena adanya vakuolisasi dan eksfoliasi sehingga metabolisme sel juga terganggu. Kelainan tersebut merupakan indikator adanya gangguan spermatogenesis. Dari satu spermatogonium setelah mengalami fase mitosis dan meiosis akan tebentuk dua spermatosit primer kemudian menhasilkan empat spermatid dan empat spermatozoa (Poernomo BS, Widjiati, Mafruchati, M Lugman 2011).

Penurunan jumlah spermatosit dan spermatid juga didukung oleh pernyataan Everrit and Johnson.M (1990) bahwa sel spermatogenik sangat peka terhadap pengaruh luar dan cenderung mengalami kerusakan setelah profase meiosis pertama yaitu pada saat terjadinya pindah silang antara kromosom yang homolog. Pada tahap ini, inti serta sitoplasma tumbuh menjadi sel terbesar diantara lapisan sel spermatogenik, namun jika adanya bahan oksidan dalam proses spermatogenesis maka akan berpengaruh terhadap jumlah sel spermatogenik.

Flavonoid yang dihasilkan oleh hampir sebagian besar dunia tumbuhan dapat menghambat banyak reaksi oksidasi, baik enzim maupun non enzim (Robinson, dalam Nurliani A, Rusmiati 2005). Kellis dan Vickery (1984) berpendapat bahwa Flavonoid yang disintesis hampir seluruh dunia tumbuhan dapat menghambat enzim aromatase. Dengan dihambatnya enzim tersebut yang berfungsi mengkatalis konversi androgen menjadi estrogen, maka jumlah testosteron (Androgen) akan meningkat (Hartini 2011). Selain itu flavonoid diduga sebagai inhibitor dalam penurunan laju reaksi. Ikatan inhibitor dapat merubah daya katalisator nya, karena adanya perubahan struktur enzim ketika suatu inhibitor maupun katalisator berinteraksi dengan enzim tersebut (Boyer dalam Basha H.S , Lalithamma A, Lakshman J 2013). Hal ini dikarenakan beberapa senyawa bioaktif asal tumbuhan ketika ditambahkan ke dalam sistem reaksi enzimatik dapat berperan sebagai aktifator dan beberapa justru sebagai inhibitor. Dengan bertambahnya jumlah reaksi enzimatik di 
dalam tubuh seperti enzim primer SOD (Superoksida Dismutase), maka akan menghambat sejumlah proses perkembangan sel didalam tubuh termasuk spermatogenesis.

Gaytan dan Aguilar (1987) menyatakan bahwa jumlah sel sertoli dalam testis tikus lebih dikontrol oleh hormon FSH sedangkan menurut Fritz (1978) perkembangan dan jumlah sel spermatogonia serta sel sertoli lebih dipengaruhi oleh regulasi hormonal. Apabila kadar hormon (FSH dan LH) mencukupi kebutuhan sel dan jaringan pada organ reproduksi maka testis juga akan berfungsi dengan baik. Namun untuk mengetahui mekanisme kerja secara jelas dari efek sitotoksik dan sitostatik tersebut masih perlu dilakukan penelitian lebih lanjut.

\section{SIMPULAN DAN SARAN}

\section{Simpulan}

Pemberian ekstrak daun jambu biji merah dosis $40 \mathrm{mg} / \mathrm{ml} / \mathrm{hari}$ dan $80 \mathrm{mg} /$ $\mathrm{ml} / \mathrm{hari}$ tidak menurunkan jumlah sel spermatogonium pada tikus putih jantan. Pemberian ekstrak daun jambu biji merah 40 $\mathrm{mg} / \mathrm{ml} / \mathrm{hari}$ dan $80 \mathrm{mg} / \mathrm{ml} / \mathrm{hari}$ tidak menurunkan jumlah spermatosit primer pada model tikus putih jantan. Pemberian ekstrak daun jambu biji merah $40 \mathrm{mg} / \mathrm{ml} / \mathrm{hari}$ dan 80 $\mathrm{mg} / \mathrm{ml} /$ hari menurunkan jumlah spermatid pada model tikus putih jantan.

\section{Saran.}

Perlu dilakukan penelitian lebih lanjut apakah ekstrak daun jambu biji merah berpengaruh terhadap jumlah sel sertoli dan kadar inhibin pada tikus putih jantan, Perlu dilakukan penelitian lebih lanjut apakah ekstrak daun jambu biji merah berpengaruh terhadap testis ( ukuran dan berat testis), Perlu dilakukan penelitian lebih lanjut apakah ekstrak daun jambu biji merah berpengaruh terhadap kadar hormon FSH, LH dan Testosteron pada tikus putih jantan, Perlu penelitian lebih lanjut efek toksik ekstrak daun jambu biji merah terhadap organ reproduksi, Perlu dilakukan penelitian lebih lanjut dengan dosis yang lebih tinggi, waktu pemberian yang lebih lama dan sampel yang lebih banyak.

\section{KEPUSTAKAAN}

Astuti NY dan Soeradi O, 2002. Toksisitas akut dan efek pemberian ekstrak etanol kayu secang (Caesalpinia sappan L) terhadap struktur anatomi tubulus Seminiferus testis tikus putih. Jurnal Bahan Alam Indonesia, 1(1).

Basha H.S , Lalithamma A, Lakshman J, C.C., 2013. Antifertility effect of carica papaya linn.seed extract on hormones in male albino rats. International Journal of Biological \& Pharmaceutical Research, 4(12), pp.859-861.

Everrit and Johnson.M, 1990. Essensial Reproduction 3 nd Editi., London: Blackwell Sci.Pub.

Fritz, I.B., 1978. Site of actions of androgen and follicle stimulating hormone on cell of the seminiferous tubule, New York: Litwack (Ed) Academic Press.

Ganong. WF, 2003. Buku ajar fisiologi kedokteran Ed. 20., Jakarta: EGC.

Harjopranjoto. S, 1995. Ilmu kemajiran pada ternak. surabaya, Surabaya: Airlangga University Press.

Hartini, 2011. Pengaruh dekok daun jambu biji merah (Psidium guajava. L) terhadap jumlah , kecepatan dan morfologi spermatozoa tikus putih jantan (Rattus norvegicus). universitas andalas.

Moeloek. N, 1994. Sistem reproduksi jantan/pria. reproduksi dan embriologi : dari satu sel menjadi organisme, Jakarta: FKUI.

Nurliani A, Rusmiati, S.H.., 2005. Perkembangan sel spermatogenik mencit (Mus musculus L) setelah pemberian ekstrak kulit kayu durian (Durio ziberthinus murr.). Jurnal Berk. Penel. Hayati, 11, pp.77-79.

Poernomo BS, Widjiati, Mafruchati, M Lugman, E., 2011. Buku ajar embriologi, Surabaya: Pusat Penerbitan dan Percetakan Universitas Airlangga.

Prajogo. B, 2003. Dikembangkan kontrasepsi 
Jurnal Ners Vol. 11 No. 2 Oktober 2016: 269- 276

hormonal pria. Available at: http://www.kontrasepsihormonalpria.co $\mathrm{m} / \mathrm{kes}$.

Speroff L \& Fritz, M., 2005. Clinical gynecology endocrinology and infertility, Philadelphia: Lippincot William \& Wilkins.
Susetyarini. Rr. E, 2009. Efek senyawa aktif daun beluntas terhadap kadar testosteron tikuspPutih (Rattus norvegikus) jantan. Jurnal GAMMA, V(1), pp.21-27. 